\title{
CARDIAC PARAGANGLIOMA FOUND DURING ANGINA EVALUATION
}

\author{
A. QAMAR ${ }^{1}$, M. VAYNBLAT ${ }^{2}$, M. KOECKERT ${ }^{2}$, F. ZHOU ${ }^{3}$, A. BABAEV ${ }^{1}$ \\ ${ }^{1}$ Cardiac Catheterization Laboratories, Leon H. Charney Division of Cardiology, Department of Medicine, New York University Grossman School of Medicine, \\ New York, USA \\ 2 Division of Cardiothoracic Surgery, New York University Grossman School of Medicine, New York, USA \\ 3 Department of Pathology, New York University Grossman School of Medicine, New York, USA
}

Cardiac paragangliomas are an extremely rare cause of cardiac masses. We present a case of a cardiac paraganglioma presenting as a highly vascular mass on coronary angiography in a patient with angina, we discuss the challenges in its diagnostic evaluation and management.

Keywords: Paraganglioma, heart, tumor, diagnosis.

Для цитирования: Qamar A, Vaynblat M, Koeckert M, Zhou F, Babaev A. Cardiac paraganglioma found during angina evaluation. Vestnik Avitsenny [Avicenna Bulletin]. 2020;22(4):655-9. Available from: https://doi.org/10.25005/2074-0581-2020-22-4-655-659

\section{ПАРАГАНГ АИОМА СЕРДЦА, ОБНАРУЖЕННАЯ У ПАЦИЕНТА СО СТЕНОКАРДИЕЙ}

\author{
А. КАМАР ${ }^{1}$, М. ВАЙНБЛАТ ${ }^{2}$, М. КОЕКЕРТ ${ }^{2}$, Ф. ДЖУ ${ }^{3}$, А. БАБАЕВ ${ }^{1}$ \\ 1 Отделение интервенционной кардиологии, кафедра кардиологии, Школа медицины им. Гроссмана, Нью-Йоркский медицинский университет, Нью- \\ Йорк, США \\ 2 Отделение сердечно-торакальной хирургии, Школа медицины им. Гроссмана, Нью-Йоркский медицинский университет, Нью-Йорк, США \\ 3 Отделение патологической анатомии, Школа медицины им. Гроссмана, Нью-Йоркский медицинский университет, Нью-Йорк, США
}

Кардиальные параганглиомы - крайне редкая опухоль сердца. Описан случай сердечной параганглиомы, выявленной при коронарной ангиографии у пациента со стенокардией в виде гиперваскуляризированного объёмного образования. Обсуждены особенности диагностики и лечения параганглиомы сердца.

Ключевые слова: параганглиома, сердце, опухоль, диагностика.

For citation: Qamar A, Vaynblat M, Koeckert M, Zhou F, Babaev A. Cardiac paraganglioma found during angina evaluation. Vestnik Avitsenny [Avicenno Bulletin]. 2020;22(4):655-9. Available from: https://doi.org/10.25005/2074-0581-2020-22-4-655-659

\section{HISTORY OF PRESENTATION}

A 58-year-old man was referred by his cardiologist for an elective coronary angiography for the evaluation of dyspnea and left arm discomfort on exertion. Symptoms completely resolved with rest. His symptoms started 2-months prior to presentation and had been slowly worsening. The patient's medical history was remarkable for essential hypertension (nebivolol $5 \mathrm{mg} / \mathrm{d}$ ), hyperlipidemia (atorvastatin $40 \mathrm{mg} / \mathrm{d}$ ) and current smoking ( 0.5 packs/day for 40 years); there was no history of diabetes mellitus, coronary artery disease (CAD), stroke or heart failure. He retired from professional boxing 20 -years ago and had no family history of CAD.

On physical examination, his body mass index was $36.9 \mathrm{~kg} / \mathrm{m}^{2}$ (5.5 ft.; $103 \mathrm{~kg}$ ), blood pressure 104/75 mm Hg with a heart rate of 63 bpm. Jugular venous pulsations were normal. Carotid upstroke was brisk, and there were no bruits. Lungs were clear to auscultation. The first and the second heart sounds were within normal limits; there were no murmurs, rubs, or gallops. The lower extremity pulses were normal and there was no lower extremity edema. A 12-lead electrocardiogram performed on the day of coronary angiography showed normal sinus rhythm and was otherwise unremarkable.

He underwent an exercise nuclear myocardial perfusion study 5-weeks prior to coronary angiography exercising for 2.8 minutes on a standard Bruce protocol achieving a peak heart rate of $139 \mathrm{bpm}$ ( $86 \%$ of maximum predicted heart rate), blood pressure of 142/90 $\mathrm{mm} \mathrm{Hg}$ and maximal workload of 7.0 METS. Technetium-99m stress myocardial perfusion imaging showed a medium-sized, moderate intensity, partially reversible defects in the proximal to distal lateral wall segments, apex and a medium-sized, moderate to severe intensity significantly reversible defects in the proximal to distal inferior segments. The left ventricular ejection fraction was normal at rest and stress with no regional wall motion abnormalities.

Because of his symptoms and abnormal stress test, the patient's cardiologist thought that the patient's clinical presentation was consistent with stable ischemic heart disease and medical therapy was initiated. The patient was treated with aspirin $(81 \mathrm{mg} / \mathrm{d})$, metoprolol extended-release formulation $(50 \mathrm{mg} / \mathrm{d})$, transdermal nitroglycerin patch $(0.1 \mathrm{mg} / \mathrm{h}$ for $24 \mathrm{~h})$, atorvastatin $(40 \mathrm{mg} / \mathrm{d})$ and nebivolol was discontinued. On this medical regimen, the patient experienced a mild improvement in exertional left arm pain; however, dyspnea remained unchanged. Given persistent symptoms, a decision was made to perform diagnostic coronary angiography.

Coronary angiography was performed via transfemoral access using $6 \mathrm{~F}$ catheters. The dominant right coronary artery had mild atherosclerosis. The left main coronary artery was angiographically normal. The left anterior descending (LAD) had a diffuse severe $(80 \%)$ stenosis in the mid-portion. The first diagonal branch had a diffuse severe $(80 \%)$ stenosis proximally. A large and highly vascular mass (approximately $5 \times 5 \mathrm{~cm}$ ) was seen in the anterior aspect of the heart during contrast injection in the left coronary artery (Fig. 1, 2). This mass appeared to be in close proximity to the mid LAD. 


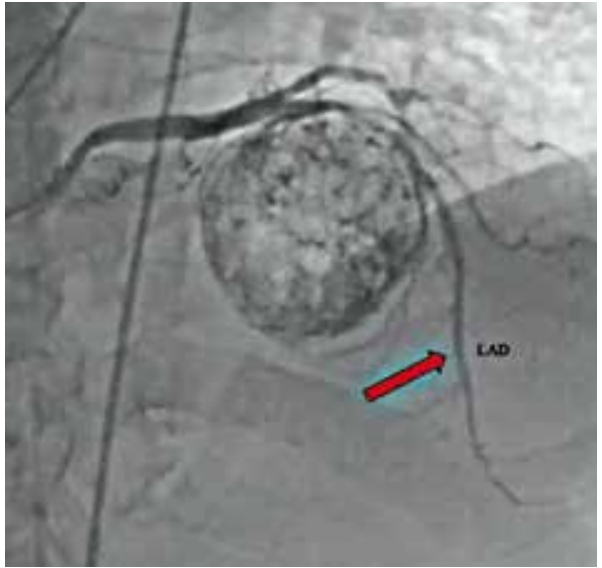

Fig. 1 Right anterior oblique view of the left anterior descending coronary artery (arrow) on angiography supplying as well-demarcated mass

$\angle A D$ - left anterior descending coronary artery

\section{DifFERENTIAL DIAGNOSIS}

The differential diagnoses of a vascular cardiac mass include cardiac myxoma (most common), lipomas, fibromas, fibroelastic papilloma's, rhabdomyomas, hamartomas, angiosarcomas, rhabdomyosarcoma, leiomyosarcoma, lymphoma, mesothelioma and paraganglioma.

\section{INVESTIGATIONS}

After completion of coronary angiography, the patient underwent transthoracic echocardiography with definity microbubble contrast the same day. The echocardiogram showed normal left ventricular size and function, normal left ventricular thickness, normal left atrium, normal right atrium, normal right ventricle and no significant valvular abnormalities. A large $5 \times 5 \mathrm{~cm}$ mass was seen along the anterior aspect of the heart that appeared to be located extrinsic to the heart rather than intracardiac (Fig. 3). After definity echo contrast injection, there was significant uptake of the contrast by the mass suggesting that the mass was significantly vascular. There was no pericardial effusion.

The cardiac MRI was then performed to further evaluate tumor, it showed a large, smooth-walled, well-circumscribed, $4.5 \times 4.4$ $\mathrm{cm}$ cardiac mass adjacent to the left ventricular anterior wall (Fig.

Fig. 3 A short-axis view of transthoracic echocardiogram showing a large $5 \times 5 \mathrm{~cm}$ geterogenous mass (arrow) along the arterior aspect of the heart that appeared to be located extrinsic to the heart rather than intracardiac

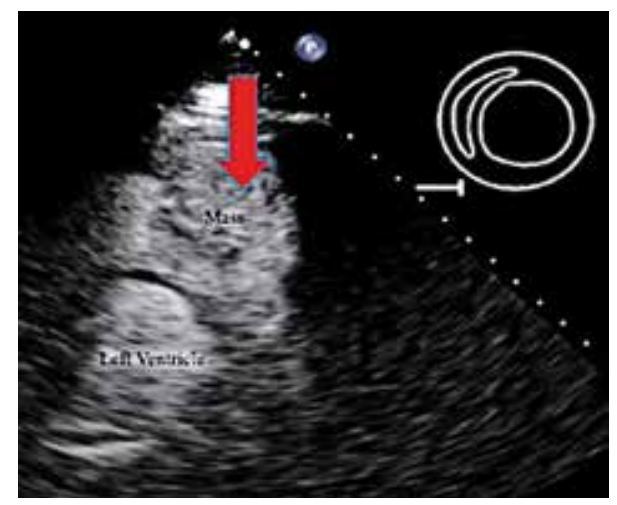

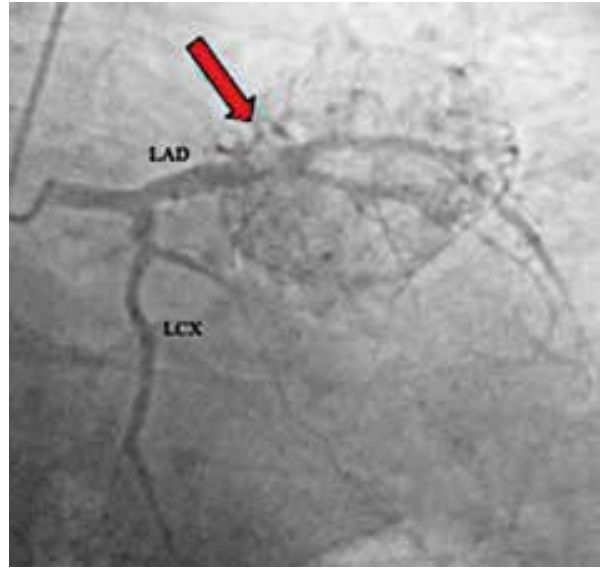

Fig. 2 Right anterior oblique caudal view of the left anterior descending coronary artery on angiography supplying as well-demarcated mass (arrow)

$\angle A D$ - left anterior descending coronary artery

LCX - left circumflex coronary artery

4). The mass was isointense on T1-weighted images, and markedly hyperintense on T2-weighted images, and showed diffuse enhancement on first-pass perfusion images as well as enhancement on late gadolinium imaging (Fig. 5). There was mild obstruction of the right ventricular outflow tract and the main pulmonary artery from the mass. The remaining cardiac structures were normal. The cardiac MRI incidentally found an enlargement of the right parotid gland for which a positron emission tomography/computed tomography (PET-CT) was recommended to rule out metastatic malignancy. The whole-body PET-CT was performed and showed high $18 \mathrm{~F}$ fluorodeoxyglucose avidity in the cardiac mass and the parotid gland (Fig. 6). A fine-needle aspiration biopsy of the right parotid gland was performed and was normal.

\section{MANAGEMENT}

Based on the findings, a decision was made to proceed with surgical resection of the mass and coronary artery bypass grafting of the LAD. Intraoperatively, the patient was placed on cardiopulmonary bypass, after the pericardium was opened, the mass was seen anterior to the basal anteroseptal wall of the left ventricle. The mass was resected and the severe lesion in the mid LAD was bypassed with a pedicle left internal mammary artery graft. The patient had an

Fig. 4 T2 fat saturated short-axis image on cardiac MRI showing hyperintense mass (arrow)

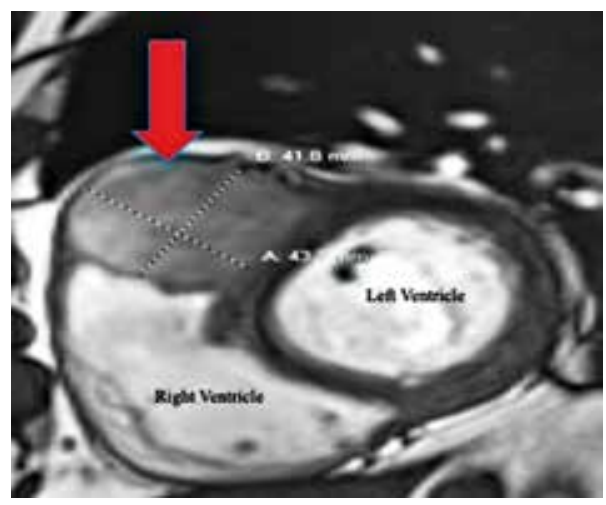




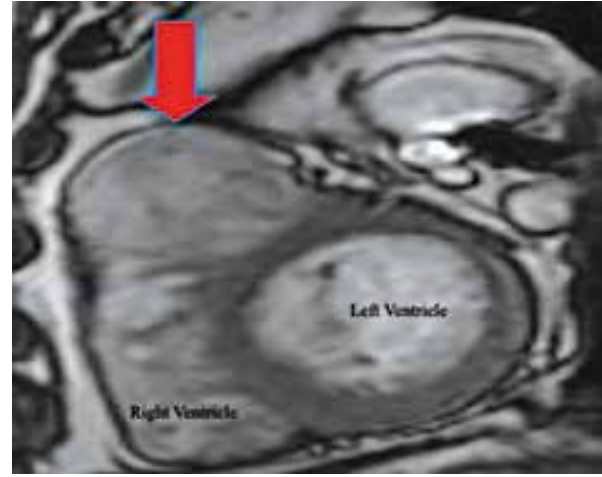

Fig. 5 No delayed enhancement mass on cardiac MRI (arrow)

excellent post-operative recovery and was discharged to home on a post-operative day 5 .

The resected mass was pigmented and measured $4.8 \times 4.2 \times 2.7$ $\mathrm{cm}$ (Fig. 7). Microscopic examination demonstrated small nests of neuroendocrine cells («Zellballen pattern») with interspersed small blood vessels. There was significant nuclear pleomorphism with cellular apoptosis (Fig. 8, 9). There was no remarkable mitosis or vascular invasion. Immunohistochemical staining was positive for CD68 (macrophages), chromogranin, synaptophysin, S100, SOX-10, and FLI-1. The tumor cells were negative for CD31, ERG, SMA, desmin, myogenin, PAX8 and Congo red. The Ki67 proliferation index was low (1-5\%). These pathological features are characteristic of paraganglioma.

\section{DiscusSiON}

Paragangliomas are benign tumors arising from chromaffin cells of extra-adrenal sympathetic ganglia and have been reported throughout the body [1]. Cardiac paragangliomas are among the rarest of cardiac tumors and account for $<0.5 \%$ of all primary cardiac tumors [2]. To date, less than 50 cases of cardiac paragangliomas have been reported all over the world. In the heart, the paragangliomas may originate from the chromaffin cells located in the cardiac chambers, atrioventricular groove, or from the nerve plexuses around the coronary arteries [3]. The commonly reported sites of cardiac paragangliomas include the left atrium (most common), right atrium, inter-atrial septum, and the left ventricle. They usually occur in middle-aged adults ( $\sim 40-50$ years) with no gender predilection. $\sim 30-$ $50 \%$ of cardiac paragangliomas are functionally active and secrete

Fig. 7 Gross specimen of the resected mass showing pigmented globular appearance

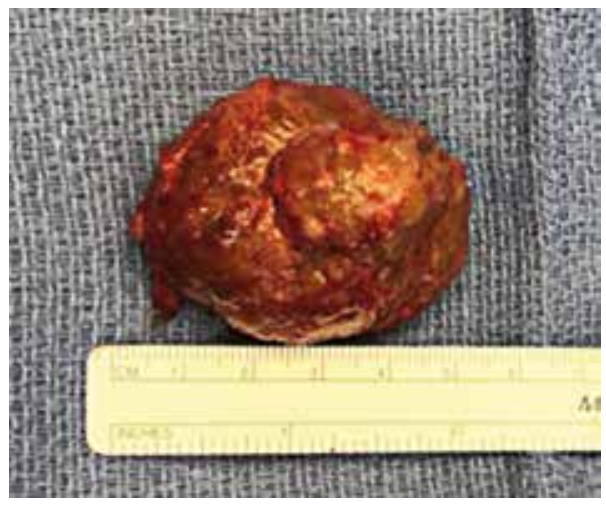

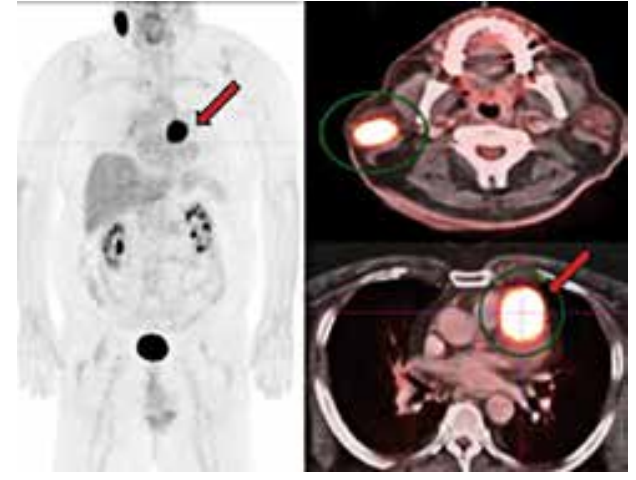

Fig. 6 Increased FDG uptake in the parotid gland (apper panel) and around the left ventricle (lower panel)

catecholamines [4]. Most cardiac paragangliomas are found incidentally. However, few patients may present with cardiac symptoms if the paraganglioma compresses coronary blood flow, has pericardial involvement, interferes with valvular function or invades the conduction system [5, 6]. Cardiac paragangliomas that are metabolically active may result in symptoms of catecholamine excess like weight loss, diaphoresis, hypertension, and palpitations. Up to $10 \%$ of paragangliomas could be malignant. Most cardiac paragangliomas are initially detected as a cardiac mass on echocardiography. Subsequently, dynamic contrast-enhanced cardiac CT or MRI is needed to provide comprehensive delineation of the mass prior to surgical resection [7]. Radionuclide imaging (e.g., 18F fluorodeoxyglucose, fluorodeoxyglucose-positron emission tomography and Tc-99m Octreotide scan) may help localize metastatic or catecholamine secreting paragangliomas; however, their routine use is not recommended.

Surgical resection is the definitive treatment of cardiac paragangliomas. Preoperative treatment with $\alpha$ and $\beta$ blockers are recommended for catecholamine secreting paragangliomas. Longterm survival of patients with localized paragangliomas is similar to the age-matched general population if complete surgical section is achieved. Conversely, patients with malignant paragangliomas have a 5 -year survival of $<50 \%$ as compared to healthy people in their age groups. While, patients with benign paraganglioma do not require further testing after surgical resection, annual biochemical testing and imaging (CT, MRI or PET-CT) is recommended for patients with malignant paraganglioma.

Our patient's symptoms of exertional dyspnea and left arm pain (an anginal equivalent) was likely secondary to severe stenosis of the left anterior descending coronary artery and the diagnosis of cardiac paraganglioma was probably an incidental finding. However, the cardiac MRI showed mild right ventricular outflow tract and the main pulmonary artery compression from the paraganglioma and may have contributed to patient's dyspnea in addition to coronary artery disease. After coronary angiography, we were concerned that the patient had a cardiac tumor. Our patients cardiac MRI showed enhanced first-pass perfusion suggesting a highly vascular nature of the tumor. This narrowed our differential of the mass to highly vascular cardiac tumors which includes hemangioma, angiosarcomas, and paraganglioma. Whole-body PET-CT ruled out metastatic disease in our patient. We did not perform biochemical testing of catecholamine levels because our patient did not have symptoms or signs suggesting of hyperadrenergic state. Correspondingly, we did not treat our patient with preoperative $\alpha$ and $\beta$ blockers. Our patient's diagnosis of benign paraganglioma was confirmed by histopathology after surgical resection. 


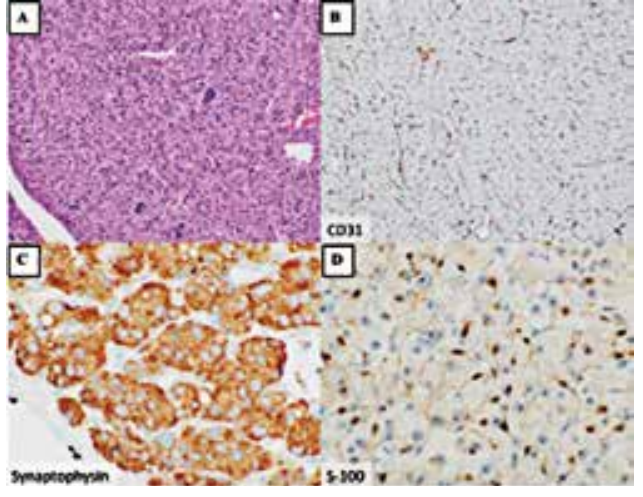

Fig. 8 Hematoxilin-eosin staining showing small nests of neuroendocrine cells with interspersed small blood vessels (A), negative CD31 (B), positive synaptophysin (C), and positive S-100 staining (D)

\section{FOLLOW-UP}

After being discharged, our patient completed cardiac rehabilitation, and his cardiac symptoms resolved. At 5 months after surgery, he was emergently admitted to our hospital with fevers, dyspnea and hypoxia leading to a diagnosis of coronavirus disease 2019 (COVID-19) pneumonia. Diagnostic evaluation during this hospitalization showed very high levels of D-dimer $(3,111 \mathrm{ng} / \mathrm{mL}$; nor-

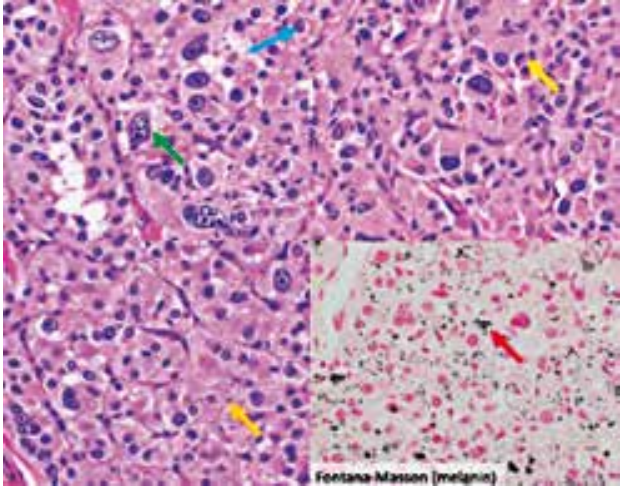

Fig. 9 High magnification Hematoxylin-eosin staining showing small nests of neuroendocrine cells with interspersed small blood vessels

$\mathrm{mal}=<230 \mathrm{ng} / \mathrm{mL}$ ) and ferritin (824 ng/mL; normal=22-248 ng/mL). Chest X-ray showed diffuse reticulonodular opacities. Transthoracic echocardiogram showed no cardiac masses, normal right and left ventricular systolic function and no evidence of pericardial effusion. He rapidly progressed to hypoxic respiratory failure and acute respiratory distress syndrome and was placed on mechanical ventilation. Despite medical therapy, he showed no signs of improvement and died on day 24 of hospitalization.

\section{REFERENCES}

1. Erickson D, Kudva YC, Ebersold MJ, Thompson GB, Grant CS, van Heerden JA, Young WF. Benign paragangliomas: clinical presentation and treatment outcomes in 236 patients. J Clin Endocrinol Metab. 2001;86:5210-6.

2. Wen J, Li H-Z, Ji ZG, Mao QG, Shi BB, Yan WG. A decade of clinical experience with extra-adrenal paragangliomas of retroperitoneum: Report of 67 cases and a literature review. Urol Ann. 2010;2(1):12-6.

3. Brown ML, Zayas GE, Abel MD, Young WF, Schaff HV. Mediastinal paragangliomas: The Mayo Clinic experience. Ann Thorac Surg. 2008;86:94651.
4. Jebara VA, Uva MS, Farge A. Cardiac pheochromocytomas. Ann Thorac Surg. 1992;53(2):356-61.

5. Turley A, Hunter S, Stewart M. A cardiac paraganglioma presenting with atypical chest pain. Eur J Cardiothoracic Surg. 2005;28:352-4.

6. Yadav PK, Baquero GA, Malysz J, Kelleman J, Gilchrist IC. Cardiac paraganglioma. Circ Cardiovasc Interv. 2014;7(6):851-6.

7. Wang ZJ, Reddy GP, Gotway MB, Yeh BM, Hetts SW, Higgins CB. CT and MR imaging of pericardial disease. Radiographics. 2003;23:S167-S180.

\section{(i) AUthor information}

Arman Qamar, MD, MPH, Interventional Cardiology Fellow, Cardiac Catheterization Laboratories, Leon H. Charney Division of Cardiology, Department of Medicine, New York University Grossman School of Medicine

Mikhail Vaynblat, MD, Professor of Surgery, Division of Cardiothoracic Surgery, New York University Grossman School of Medicine

Michael Koeckert, MD, Cardiothoracic Surgery Fellow, Division of Cardiothoracic Surgery, New York University Grossman School of Medicine

Fang Zhou, MD, Attending Physician, Department of Pathology, New York University Grossman School of Medicine

Anvar Babaev, MD, PhD, Clinical Professor of Medicine, Cardiac Catheterization Laboratories, Leon $\mathrm{H}$. Charney Division of Cardiology, Department of Medicine, New York University Grossman School of Medicine

Information about the source of support in the form of grants, equipment, and drugs

The authors did not receive financial support from manufacturers of medicines and medical equipment

Conflicts of interest: The authors have no conflicts of interest

\section{(1) СВЕДЕНИЯ ОБ АВТОРАХ}

Арман Камар, резидент, отделение интервенционной кардиологии, Школа медицины им. Гроссмана, Нью-Йоркский медицинский университет

Михаил Вайнблат, профессор кафедры сердечно-торакальной хирургии, Школа медицины им. Гроссмана, Нью-Йоркский медицинский университет

Майкл Коекерт, резидент, кафедра сердечно-торакальной хирургии, Школа медицины им. Гроссмана, Нью-Йоркский медицинский университет

Фэнг Джу, ассистент кафедры патанатомии, Школа медицины им. Гроссмана, Нью-Йоркский медицинский университет

Анвар Бабаев, профессор кафедры кардиологии, Школа медицины им. Гроссмана, Нью-Йоркский медицинский университет

Информация об источнике поддержки в виде грантов, оборудования, лекарственных препаратов

Финансовой поддержки со стороны компаний-производителей лекарственных препаратов и медицинского оборудования авторы не получали

Конфликт интересов: отсутствует 


\section{ADDRESS FOR CORRESPONDENCE:}

Anvar Babaev, MD, PhD

Clinical Professor of Medicine, Cardiac Catheterization Laboratories, Leon H. Charney Division of Cardiology, Department of Medicine, New York University Grossman School of Medicine

530 First Avenue, New York, NY 10016

Tel.: +1 (212) 2635656

E-mail: anvar.babaev@nyulangone.org

\section{AUTHOR CONTRIBUTIONS}

Conception and design: $\mathrm{AB}, \mathrm{MV}$

Data collection: $A Q, M K, F Z$

Analysis and interpretation: MV, FZ

Writing the article: $A Q, M K$

Critical revision of the article: $A B, M V$

Overall responsibility: $A B$

\section{АДРЕС ДЛЯ КОРРЕСПОНДЕНЦИИ:}

Anvar Babaev, MD, PhD

Clinical Professor of Medicine, Cardiac Catheterization Laboratories, Leon H. Charney Division of Cardiology, Department of Medicine, New York University Grossman School of Medicine

530 First Avenue, New York, NY 10016

Тел.: +1 (212) 2635656

E-mail: anvar.babaev@nyulangone.org

\section{ВКЛАД АВТОРОВ}

Разработка концепции и дизайна исследования: АБ, МВ Сбор материала: АК, МК, ФД

Анализ полученных данных: МВ, ФД

Подготовка текста: АK, MK

Редактирование: АБ, МB

Общая ответственность: АБ

Поступила

12.11.2020

Принята в печать 28.12.2020 